\title{
INTENSITAS PEMBELAJARAN TEMATIK INTEGRATIF MELALUI PENDEKATAN SAINTIFIK DI SD KESTALAN SURAKARTA
}

\author{
Oktiana Handini' ${ }^{1}$, Soewalni Soekirno ${ }^{2}$ \\ Universitas Slamet Riyadi \\ e-mail: handinioktiana@yahoo.co.id
}

\begin{abstract}
This community service aims (1). Providing a scientific basis for elementary school teachers in implementing learning that is oriented towards active, effective and enjoyable learning. (2). Provide theoretical clarity and a better understanding of learning, learning objects and the situations and conditions of learning in elementary schools. (3). Contribute ideas to education managers in an effort to improve teacher professional competency and learner ability in elementary schools, especially at SD Kestalan Surakarta. Community service is carried out in an effort to deliver competence in terms of Integrative Thematic Learning Intensity through Scientific Approach at Kestalan Elementary School Surakarta as a partner school in the Surakarta Teacher Training and Education Faculty, followed by 26 teachers and Principals with a 6-hour implementation period, starting at 8:00 p.m. until 15:00 p.m. The outcome of this community service is that community service resulted in the delivery of material on the Scientific approach to integrative thematic learning in Primary Schools in an effort to optimize teacher understanding and implementation in primary schools in general and SD Kestalan Surakarta in particular. The expected results from the implementation of this service can provide an understanding of the Intensity of Integrative Thematic Learning through the Scientific Approach in Primary Schools. So Kestalan Surakarta Elementary School teachers have 90 percent of the ability to Integrative Thematic Learning through the Scientific Approach in Primary Schools. So that the teachers can transmit their understanding to fellow teachers in the Dabin and Gugus areas as well as primary school teacher meetings. And finally, the results of this service can be published in the service journal.
\end{abstract}

Key words: Integrative Thematic Learning, Scientific Approach

\begin{abstract}
Abstrak
Pengabdian masyarakat ini bertujuan (1). Memberikan dasar ilmiah bagi guru Sekolah Dasar dalam menerapkan pembelajaran yang berorientasi pada belajar aktif, efektif dan menyenangkan. (2). Memberikan kejelasan secara teoritis dan pemahaman yang lebih baik tentang belajar, obyek belajar serta situasi dan kondisi belajar di Sekolah Dasar. (3). Memberikan kontribusi pemikiran bagi pengelola pendidikan dalam upaya meningkatkan kompetensi profesional guru dan kemampuan belajar peserta didik di Sekolah Dasar khususnya di SD Kestalan Surakarta. Pengabdian masyarakat dilakukan dalam upaya penyampaian kompetensi dalam hal Intensitas Pembelajaran Tematik Integratif melalui Pendekatan Saintifik di SD Kestalan Surakarta sebagai sekolah mitra di Fakultas Keguruan dan Ilmu Pendidikan Kota Surakarta, diikuti oleh sejumlah 26 guru dan Kepala Sekolah dengan pola waktu pelaksanaan selama 6 jam, mulai pukul 8.00 wib hingga pukul 15.00 wib . Hasil luaran pengabdian masyarakat ini adalah Pengabdian masyarakat yang dilakukan menghasilkan berupa penyampaian materi mengenai pendekatan Saintifik pada pembelajaran tematik integratif di Sekolah Dasar dalam upaya pengoptimalan pemahaman guru dan implementasinya di sekolah dasar pada umumnya dan SD Kestalan Surakarta pada khususnya. Hasil yang diharapkan dari pelaksanaan pengabdian ini dapat memberikan pemahaman tentang Intensitas Pembelajaran Tematik Integratif melalui Pendekatan Saintifik di Sekolah Dasar. Sehingga guru-guru SD Kestalan Surakarta memiliki 90 persen kemampuan tentang Pembelajaran Tematik Integratif melalui Pendekatan Saintifik di Sekolah Dasar. Sehingga para guru dapat menularkan pemahamannya kepada rekan guru di wilayah Dabin dan Gugusnya maupun
\end{abstract}


musyawarah guru sekolah dasar. Dan ahkirnya hasil pengabdian ini dapat dipublikasikan pada jurnal pengabdian.

Kata Kunci: Pembelajaran Tematik Integratif, Pendekatan Saintifik

\section{PENDAHULUAN}

Perubahan kurikulum dan pengembangan pembelajaran yang dilakukan oleh pemerintah saat ini bertujuan untuk pengembangan kurikulum pendidikan di Indonesia seiring dengan kemajuan zaman. Kenyataan kondisi penyelenggaraan pendidikan di sekolah tidak secepat perubahan kurikulum tersebut. Proses pembelajaran pada Kurikulum 2013 untuk semua jenjang dilaksanakan dengan menggunakan pendekatan ilmiah (saintifik). Pembelajaran dengan pendekatan saintifik merupakan pembelajaran yang terdiri atas kegiatan mengamati (untuk mengidentifikasi hal-hal yang ingin diketahui), merumuskan pertanyaan (dan merumuskan hipotesis), mencoba/mengumpulkan data (informasi) dengan berbagai teknik, mengasosiasi/ menganalisis/mengolah data (informasi) dan menarik kesimpulan serta mengkomunikasikan hasil yang terdiri dari kesimpulan untuk memperoleh pengetahuan, keterampilan dan sikap.

\section{A. Analisis Situasi}

Para guru di sekolah dasar saat ini dalam melaksanakan pembelajaran masih klasik dan tradisional, maksudnya seperti yang biasa dilakukan masih rutinitas seharihari. Fenomena lainnya yang ada saat menunjukkan bahwa kegiatan belajar peserta didik pada umumnya masih sebatas menjalankan instruksi guru, peserta didik kurang aktif, peserta didik tidak memiliki keberanian mengungkap pendapat diri secara spontan bila tidak diberi kesempatan dan pertanyaan guru. Sehingga suasana belajar di kelas menjadi tidak kondusif dan cenderung bersifat monoton dan kaku. Keadaan seperti ini menjadi permasalahan guru dalam proses pembelajarannya, sehingga peran guru menjadi sangat dominan dalam permasalahan ini..

\section{B. Permasalahan Mitra}

Sesuai hasil observasi dan wawancara dengan beberapa guru dan kepala sekolah SD Kestalan Surakarta belum sepenuhnya menjalankan kurikulum 2013, tahun sebelum hanya kelas 1 dan kelas 4, kegiatan belajar peserta didik pada umumnya masih sebatas menjalankan instruksi guru, peserta didik kurang aktif, peserta didik tidak memiliki keberanian mengungkap pendapat diri secara spontan bila tidak diberi kesempatan dan pertanyaan guru. Sehingga suasana belajar di kelas menjadi tidak kondusif, cenderung kaku dan sedikit membosankan. Kondisi seperti ini biasanya terlihat pada jam pelajaran siang dan mata pelajaran yang tidak peserta didik senangi. Keadaan seperti ini menjadi permasalahan guru dalam proses pembelajarannya, sehingga peran guru menjadi sangat dominan dalam permasalahan ini. Sedangkan guru tidak banyak menerapkan pendekatan saintifik yang dipersyaratkan dalam pembelajaran tematik integratif dimana pembelajaran yang interaktif, komunikatif maupun membawa suasana pembelajaran yang menyenangkan. Para guru di sekolah dasar saat ini dalam melaksanakan pembelajaran masih klasik dan tradisional, maksudnya seperti yang biasa dilakukan masih rutinitas sehari-hari.

\section{Justifikasi Pengusul dan Mitra}

Pengabdian Masyarakat yang dilakukan dosen Program Studi Pendidikan Guru Sekolah Dasar dengan mengajak peran serta mahasiwa pada sekolah mitra dengan judul ,Intensitas Pembelajaran Tematik Integratif melalui Pendekatan Saintifik di SD Kestalan Surakarta sebagai sekolah mitra di Fakultas Keguruan dan Ilmu Pendidikan Kota Surakarta. Pelaksanaan pengabdian masyarakat ini telah dilakukan sesuai kesepakatan dengan pihak sekolah bahwa pihak pelaku pengabdian menyediakan materi pelatihan, menyajikan materi yang berupa presentasi dan naskah pengabdian maupun biaya penyelenggaraan berupa hidangan sedangkan sekolah mitra memfasilitasi tempat dan media presentasi berupa LCD projector dan Screen maupun sound yang diperlukan. 


\section{Manfaat Kegiatan}

Pelaksanaan kegiatan pengabdian masyarakat ini diharapkan memberikan manfaat sebagai berikut :(1). Memberikan dasar ilmiah bagi guru Sekolah Dasar dalam menerapkan pembelajaran yang berorientasi pada belajar aktif, efektif dan menyenangkan. (2). Memberikan kejelasan secara teoritis dan pemahaman yang lebih baik tentang belajar, obyek belajar serta situasi dan kondisi belajar di Sekolah Dasar. (3). Memberikan kontribusi pemikiran bagi pengelola pendidikan dalam upaya meningkatkan kompetensi profesional guru dan kemampuan belajar peserta didik di Sekolah Dasar khususnya di SD Kestalan Surakarta.

\section{METODE PELAKSANAAN}

\section{A. Waktu dan Tempat}

\section{Waktu}

Kegiatan pengabdian masyarakat ini berlangsung selama tiga bulan, diawali pembuatan proposal pengajuan pada ahkir bulan Maret 2018 hingga Junii 2018. Pelaksanaan pengabdian dilaksanakan, Selasa 12 Juni 2018.

\section{Tempat}

Tempat pelaksanaan pengabdian di SD Kestalan Surakarta, bersamaan pada hari tersebut bertepatan dengan pertemuan dewan guru dan kepala sekolah di SD dan hadir pula perwakilan komite sekolah beserta perwakilan orangtua wali peserta didik SD Kestalan Surakarta.

\section{B. PROSEDUR KERJA}

Adapun jadwal pelaksanaan adalah sebagai berikut :

Tabel 1. Jawdal Pelaksanaan

\begin{tabular}{|c|c|c|c|}
\hline No & Pukul & Kegiatan & Keterangan \\
\hline 1 & $\begin{array}{l}08.00 \\
08.30\end{array}$ & Pembukaan & Panitia \\
\hline 2 & $\begin{array}{l}08.30 \\
10.30\end{array}$ & $\begin{array}{l}\text { Presentasi Paparan } \\
\text { Intensitas } \\
\text { Pembelajaran } \\
\text { Tematik Integratif } \\
\text { melalui Pendekatan } \\
\text { Saintifik di Sekolah } \\
\text { Dasar dilanjutkan } \\
\text { tanya jawab }\end{array}$ & $\begin{array}{l}\text { Oktiana } \\
\text { Handini, } \\
\text { S.Pd. MPd. }\end{array}$ \\
\hline 3 & $\begin{array}{l}10.30 \\
12.00\end{array}$ & $\begin{array}{l}\text { Paparan rancangan } \\
\text { pembelajaran } \\
\text { melalui } \\
\text { dilanjutkan } \\
\text { jawab }\end{array}$ & $\begin{array}{l}\text { Dr. Soewalni } \\
\text { Soekirno, } \\
\text { M.Pd. }\end{array}$ \\
\hline 4 & $\begin{array}{l}12.00 \\
13.00\end{array}$ & Ishoma & Panitia \\
\hline 5 & $\begin{array}{l}13.00 \\
15.00\end{array}$ & $\begin{array}{ll}\text { Simulasi dan } \\
\text { pendampingan } \\
\text { Penyusunan }\end{array}$ & $\begin{array}{l}\text { Berkelompok } \\
\text { dipandu oleh } \\
\text { Oktiana }\end{array}$ \\
\hline
\end{tabular}

\begin{tabular}{|l|l|l|l|}
\hline & & Rancangan & Handini, S Pd \\
& & Pembelajaran & M Pd. dan Dr. \\
& & Tematik Integratif & Soewalni \\
& & melalui Pendekatan & Soekirno, \\
& & Saintifik di Sekolah & M.Pd dibantu \\
& & Dasar melalui RPP & Devi \\
& & & Musrifah \\
\hline 6 & 15.10 & Penutup & Panitia \\
\hline
\end{tabular}

\section{Hasil Dan Pembahasan}

Hasil yang setelah usainya dari pelaksanaan pengabdian ini dapat memberikan pemahaman tentang Intensitas Pembelajaran Tematik Integratif melalui Pendekatan Saintifik di Sekolah Dasar, mampu mengoptimalkan pemahaman dan penerapan Intensitas Pembelajaran Tematik Integratif melalui Pendekatan Saintifik di Sekolah Dasar. Sehingga guru-guru SD Kestalan Surakarta memiliki 90 persen kemampuan tentang Intensitas Pembelajaran Tematik Integratif melalui Pendekatan Saintifik di Sekolah Dasar, serta mampu mengembangkan rancangan pembelajaran tematik Integratif melalaui Pendekartan Saintifik secara maksimal. Diharapkan dengan usainya pengabdian masyarakat ini para guru dapat menularkan pemahamannya kepada rekan guru di wilayah Dabin dan Gugus nya maupun musyawarah guru sekolah dasar. Intensitas Pembelajaran Tematik Integratif melalui Pendekatan Saintifik di Sekolah Dasar yang telah diberikan di SD Kestalan Surakarta secara efektif membantu menciptakan pembelajaran dengan nuansa suasana baru yang mampu memberikan kesempatan yang luas bagi peserta didik untuk melihat dan membangun konsepkonsep yang saling berkaitan. Guru -guru SD Kestalan Surakarta dilatih memberikan kesempatan kepada peserta didik untuk memahami masalah yang kompleks yang ada di lingkungan sekitarnya dengan pandangan yang utuh. Dengan pembelajaran tematik integratif ini peserta didik diharapkan memiliki kemampuan untuk mengidentifikasi, mengumpulkan, menilai dan menggunakan informasi yang ada di sekitarnya secara bermakna. Hal itu dapat diperoleh tidak saja melalui pemberian pengetahuan baru kepada peserta didik melainkan juga melalui kesempatan memantapkan dan menerapkannya dalam berbagai situasi baru yang semakin beragam.

Kegiatan pendampingan implementasi praktek membuat rancangan Intensitas 
Pembelajaran Tematik Integratif melalui Pendekatan Saintifik di Sekolah Dasar dan mendiskusikannya.. Adapun langkah kegiatan dalam implementasi pembelajarannya adalah sebagai berikut :

1. Kegiatan pendahuluan :

Guru melakukan apersepsi dengan pertanyaan pada materi model-model pembelajaran Memberi pertanyaan kepada peserta didik tentang cakupan materi dari Intensitas Pembelajaran Tematik Integratif melalui Pendekatan Saintifik di Sekolah Dasar ini.

2. Kegiatan inti :

Guru melaksanakan langkah-langkah pendekatan Saintifik. Meliputi : menggali informasi melalui observing/pengamatan, questioning/bertanya,

experimenting/percobaan, kemudian mengolah data atau informasi, dilanjutkan dengan menganalisis, associating/menalar, kemudian menyimpulkan, dan menciptakan serta membentuk jaringan/networking.

3. Kegiatan Penutup :

a. Guru memberikan masukan tentang hasil pekerjaan peserta didik

b. Guru melakukan evaluasi penilaian dalam bentuk test

c. Guru peserta didik untuk memberikan masukan terhadap cara pembelajaran guru sebagai evaluasi untuk pembelajaran pada pertemuan selanjutnya merefleksi hasil pembelajaran sebagai evaluasi pembelajaran pada pertemuan berikutnya.

\section{KESIMPULAN}

Kegiatan pengabdian masyarakat tentang Intensitas Pembelajaran Tematik Integratif melalui Pendekatan Saintifik di SD Kestalan Surakarta pada guru-guru di SD Kestalan Surakarta menghasilkan kesimpulan: (1)Pengabdian masyarakat tentang Intensitas Pembelajaran Tematik Integratif melalui Pendekatan Saintifik di SD Kestalan Surakarta pada guru-guru di SD Kestalan Surakarta yang dilaksanakan dapat meningkatkan kemampuan dan keterampilan guru dalam pembelajaran tematik integratif melalui Pendekatan Saintifik di Sekolah Dasar. (2).Pengabdian masyarakat tentang Intensitas Pembelajaran Tematik Integratif melalui Pendekatan Saintifik di SD Kestalan Surakarta pada guru-guru di SD Kestalan Surakarta mampu mengoptimalkan pemahaman guru - guru dalam model pembelajaran tematik integratif melalui Pendekatan Saintifik di Sekolah Dasar.

\section{Saran}

Dari kesimpulan di atas dapat dikemukakan beberapa saran (1). SD Kestalan Surakarta mengoptimalkan pemahaman para guru - guru dalam Pengabdian masyarakat tentang Intensitas Pembelajaran Tematik Integratif melalui Pendekatan Saintifik pada guru-guru di SD Kestalan Surakarta di Sekolah Dasar yang berorientasi pada belajar peserta didik aktif dan efektif.(2). Guru-guru SD Kestalan Surakarta hendaknya memiliki kontribusi pemikiran bagi guru-guru sekolah dasar lainnya dalam upaya menerapkan dan mengimplementasikan Pembelajaran Tematik Integratif melalui Pendekatan Saintifik di Sekolah Dasar yang berorientasi pada belajar siswa aktif dan efektif dengan berbasis penciptaan suasana pembelajaran yang interaktif, nyaman dan kondusif. (3). SD Kestalan Surakarta perlu menambah sarana pendukung penbelajaran Tematik Integratif melalui Pendekatan Saintifik seperti penyediaan media dalam di dalam kelas untuk membangkitkan semangat peserta didikk dan membangun suasana dalam belajar.

\section{DAFTAR PUSTAKA}

Ahmad Susanto (2014). Teori Belajar dan Pembelajaran di Sekolah Dasar. Jakarta: Universitas Kencana Prenada Media Group.

Ahmadi Khoiron, Sofyan Amri (2014). Pengembangan Dan Model Pembelajaran Tematik Integratif, Jakarta : PT Prestasi Pustaka Karya

Andi Prastowo, (2012). Panduan Kreatif Melalui Bahan Ajar Inovatif, Yogyakarta : Diva Press 
Amstrong Thomas, (2002). The Seven Kinds of SMART Terjemahan Hernowo. Jakarta :PT Gramedia Pustaka Ilmu.

Daryanto, (2014) . Pembelajaran Tematik Terpadu Terintegrasi Kurikulum 2013.

Yogyakarta : RosdaKarya

Forgarty Robin,( 2001). How To Integrate the Curriculum, USA : Skylight Publishing Imas Kurniasih, (2014). Implementasi Kurikulum 2013, Surabaya : Kata Prima.

Mirta Eliabeth Gonzalez Maza, 2014, Exploring Teachers' Learning : A Teacher's Experiences Integrating Scientific Modelling in The Science Classroom, Urbana,Illinois.

Mecher L Karen, Christine N Holdsworth, (2006). Model and Strategies for Trainning Design, Washington : Harvard Publishing

Muhammad Surya, (2013). Psikologi Guru Konsep dan Aplikasi, Bandung : Rhineka Mulyasa E (2013). Pengembangan dan Implementasi Kurikulum 2013. Bandung: PT. Remaja Rosdakarya.

Triyanto, (2014). Desain Pengembangan dan Pembelajaran Tematik. Bandung: PT. Remaja Rosdakarya. 